\title{
Shelly, MAiD and the purple parade
}

Cite as: CMAJ 2019 June 17;191:E668-9. doi: 10.1503/cmaj.190082

CMAJ Podcasts: audio reading at https://soundcloud.com/cmajpodcasts/190082-enc

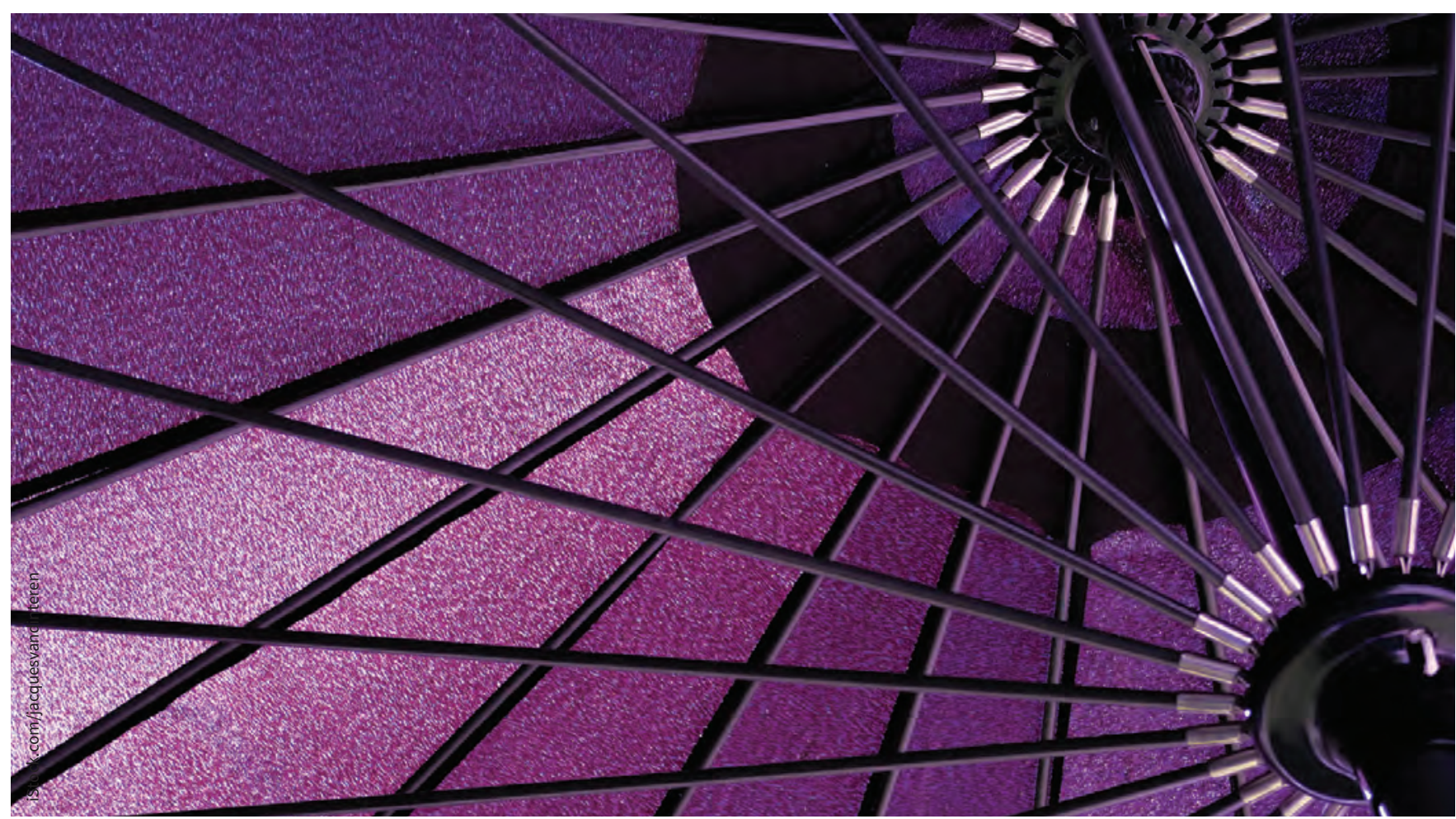

I made an appointment with my GP [general practitioner] to start the paperwork for MAiD [medical assistance in dying]."

That is what my best friend and fellow physician said to me as calmly as if we were discussing the weather.

I immediately felt nauseated.

But I wasn't really surprised. For nearly two years and through countless doctors' appointments and tests, Shelly had searched for a diagnosis for her debilitating symptoms. The ones that left her unable to do the job she loved and took a little more from her every week.

Multiple System Atrophy. No treatment, no cure and, as Shelly liked to say, "not even a run for the cure."

Shelly and I met in residency. She was a Maritimer, and I was born and raised in
Ontario. She was an eternal optimist and her laughter was infectious. We found common ground over our love for books and the stress of medical training.

We remained friends long after she moved away.

"Are you sure that is what you want to do?," or something equally inane is what I recall saying when she told me her decision. Of course, she was sure, and we both knew it. She had literally watched her mother, diagnosed with amyotrophic lateral sclerosis, starve herself to death because the legislation for MAiD had not yet passed.

"I am not ready yet, but I want to get the process started." I didn't ask her then, but what went through my mind was, "How will you know?"

"Dying creates a lot of paperwork," she told me often over the following months. She spent a few hours each day tying up the strings of her life so her husband and brothers could carry on when she was gone. With the help of friends, she also threw herself into living life as best she could. She told me she had her moments where she felt angry and sorry for herself but with me, she was still the same unsinkable Shelly.

Shelly also had another mission - to find a way to donate her organs. That was something that had not happened in her province for someone going through MAiD and there were many barriers. One by one, she struck them down and educated health professionals along the way. She gave talks from her home, rewrote educational materials and argued about silly policies that needed to be changed. 
One day, she emailed me to say her work had caught the attention of Canadian Blood Services. They wanted to do a documentary about her journey. "Should I do it?," she asked me. "Yes!," was my reply. All I could think of then was what a fantastic legacy to leave behind.

In the summer, Shelly had a "Going Away Party." She wanted to have it while she still felt well enough to enjoy it. My husband, another close friend and my parents flew out to attend. The love in the room was palpable, but so was the sadness. When the mood got too morbid, our friend would pull out a list of terrible jokes that she had prepared. Shelly loved awful jokes. We laughed and cried at the same time.

During the party, many of us were invited to speak on camera about Shelly. I was caught off guard when asked, "When she decides it is time to go to the hospital, will you be there with her?" It had not occurred to me that she would want me there. The thought horrified me because it made it too real.

Shelly and I talked about it later. She knew she had to go through with MAiD in the hospital so the transplant team could be on standby. She also knew she wanted only her husband to be at her bedside when she took her last breath. But she left the door open for a few others to come to the hospital with her, including me. Again, I felt nauseated and to my shame, I am sure she could read it on my face.

More months passed and I started to see signs in her emails that made me suspect she was coming to the end of what she could tolerate from her disease. I finally found the courage to ask her outright. In her emailed reply in the middle of a busy clinic, she told me it was happening in less than two days. In an instant, my thoughts changed from "if I was going" to "dear God, help me to get there in time." I was on a plane the following morning.

The small group of family and friends that Shelly had invited gathered in the hospital lobby. We wore purple because it was her favourite colour. And when her husband wheeled Shelly past us, we fell in behind them, a parade of Shelly's purple people.

Part of me never truly believed she would go through with MAiD. That was because I had never felt the pain she felt or lived with the terror of death piece by piece. By choosing the day of her death, she took some of her power back, and she made it possible to give the gift of life to others.
I am enormously proud of Dr. Shelly Sarwal. She was an amazing physician and a truly remarkable woman. I also await the documentary she made with Canadian Blood Services ("Her Last Project"), and pray that it opens some minds and hearts. But mostly, I just miss my friend.

"I had more living left to do but in the time I had, I tried to spread happiness, stand up for what I believed in, and not take life too seriously. Think of me when you dance or laugh or hug a dog. I'll be in the turn of a page, the silver lining, the sown seed. Remember me in my garden, in funky hats, in cute cars, and, most especially, telling bad jokes. In my memory, have a cup of tea and a good chat with your friends."

\section{Lori-Ann Linkins MD MSc(Clin Epi)}

Department of Medicine, McMaster University; Juravinski Hospital; Hamilton, Ont.

\section{Reference}

1. Shailini Sarwal: 20 August, 1970-31 August, 2018 [Obituary]. Halifax: Dignity Memorial; 2018. Available: www.dignitymemorial.com/en-ca/obituaries/ halifax-ns/shailini-sarwal-7977443 (accessed 2019 Feb. 27).

This article has been peer reviewed.

This is a true story. Dr. Sarwal's husband gave consent for it to be told. 